\title{
PHOTOMETRIC STARCH-IODINE DETERMINATION IN PLANT MATERIALS AS INFLUENCED BY ASCORBIC ACID. CRITICAL REMARKS
}

\author{
BogusŁaw SAmotus, ElżBIETA DOERre, AdAM ŚwIDERSKI, ANDRZEJ ŚCIGALSKI \\ Department of Biochemistry, University of Agriculture, \\ 31-425 Kraków, Poland
}

(Received: October, 22, 1993. Accepted: March, 25, 1994)

\begin{abstract}
Following the work of Sharma et al. (1990) on the interference of ascorbic acid (AA) with starch-iodine reaction, the present authors repeated it, giving a proper explanation of the influence of AA in this reaction. AA oxidizes iodine-iodide (I-KI) reagent which makes impossible to form the blue complex with starch. Three measures are suggested to overcome the interference of AA: 1) to titrate starch solution with I-KI reagent and thus work out an I-KI amount for development of blue coloration, 2) to remove from plant material AA (and other reducing soluble substances) by washing the material with cold water or ethanol, and 3) starch solution could be treated with alkali (pH about 9), which destroys AA in 15 minutes. After acidifying the solution and adding I-KI reagent the blue complex can be determined.
\end{abstract}

KEY WORDS: Starch-iodine complex, ascorbic acid, interference

\section{INTRODUCTION}

Owing to the classical work of McCready and Hassid (1943) starch can be estimated quantitatively using a colorimetric procedure. The procedure is simple and rapid provided that some physicochemical conditions of starch solution preparation and its determination are maintained. In a recent paper we have reported that: 1) the higher the temperature, the lower the absorbancy of the complex, 2) $\mathrm{pH}$ of the solution influences colour intensity: the same absorbancy was obtained between $\mathrm{pH}$ 1.5-2.5, but lower $\mathrm{pH}$ (1.0) diminished the absorbancy, 3) various starches (extracted from different plant materials) showed different absorbancy for the same starch concentration, 4) the removal of souble constituent from the examined material before starch solubilization was not necessary (Samotus et. al., 1993). In further experiments, however, we observed that in case of leafy materials, the removal of certain reducing substances was necessary before starch determination (unpublished data). Accordingly, the dried material $\left(70{ }^{\circ} \mathrm{C}\right.$, using draft oven) was extracted with hot $80 \%$ ethanol and the residue was solubilized in concentrated $\mathrm{CaCl}_{2}$ solution (boiling water bath, $30 \mathrm{~min}$ ). Even after adopting this strategy, ceratin materials (the leaves of carrot, tomato, broad bean and beech) revealed some amounts of reducing substances, which interrfered with the blue complex formation. To take care of such interference, it was necessary to add I-KI solution to the reaction mixture till the blue colour developed (starch in the solution served in this case as an indicator). In this manner, the amount of I-KI reagent to be used for starch estimation in a particular plant material was worked out.

Sharma et al. (1990) demonstrated a strong suppression of starch-iodine in the presence of ascorbic acid, a common plant constituent; recovery being evident when I-KI level was increased. They explained that a complex between AA and I is formed, which could account for AA-induced depletion of iodine level and, in turn, lowered the magnitude of the reaction.

We repeated the experiments performed by Sharma et al. (1990) and examined the reasons for interference of AA with starch-iodine complex formation.

\section{MATERIAL AND METHODS}

Soluble starch (Polskie Odczynniki Chemiczne, Gliwice) was used to prepare the stock solution in distilled water (100 $\mathrm{mg} / 100 \mathrm{ml}$ ). The I-KI stock solution contained $0.200 \mathrm{~g} \mathrm{I}$ in $2.000 \mathrm{~g}$ KI per $100 \mathrm{ml}$ of distilled water. Ascorbic acid (AA) solutions (chemically pure reagent) were prepared by dilution with $0.05 \mathrm{M} \mathrm{HCl}$ to prevent AA decomposition. Absorbancy of the blue starch-iodine complex was determined in $1 \mathrm{~cm}$ cell using the SPEKOL photometer at $620 \mathrm{~nm}$.

For spectral studies different concentrations of AA solutions in $0.05 \mathrm{M} \mathrm{HCl}$ as well as iodine solution in $4 \%$ ethanol and that of $\mathrm{KI}$ in water were used. The absorbancy in UV region (200-300 nm) was performed in a $1 \mathrm{~cm}$ quartz cell using the SPECORD spectrophotometer (Carl Zeiss, Jena).

\section{RESULTS}

The influence of increasing concentrations of starch, while maintaining the iodine concentration constant, are presented in Fig. 1. As is apparent, the absorbancy increased linearly with an increase in starch concentration. In contrast, the increasing concentration of I-KI reagent applied to constant 


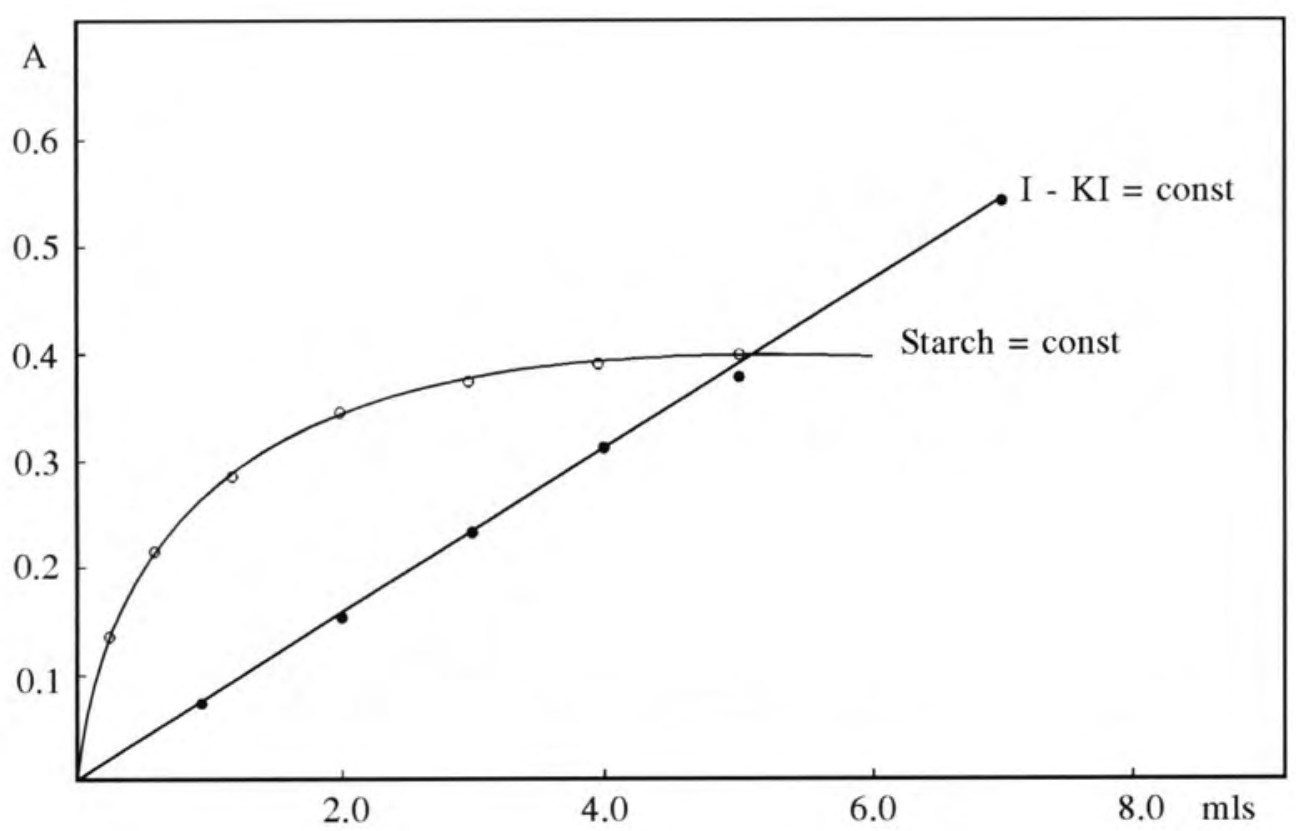

Fig. 1. Absorbancy of starch-iodine complex.

$\bullet-\bullet-\bullet-$ = constant concentration of I-KI $(1 \mathrm{ml}$ of stock solution diluted to $100 \mathrm{ml}$ ), and different amounts of $2 \mathrm{mg} / 100 \mathrm{ml}$ starch solution, o-o-0- = constant starch solution $(2 \mathrm{mg} / 100 \mathrm{ml})$ and different amounts of stock solution of I-KI diluted to $100 \mathrm{ml}$. starch concentration followed a hyperbolic curve, which means that in the beginning (low I-KI concentration) starch molecules were not saturated with I-KI reagent, but they reached the saturation as soon as the concentration increased (Fig. 1). Obviously, it is necessary to work out a proper I-KI concentration to have reproducible results. The same conclusion was drown by Sharma et al. (1990).

The above experiments were repeated with a double concentration of $\mathrm{KI}$ to check the interference of this reagent on blue complex absorbancy and no difference in the absorbancy was observed.

Ascorbic acid revealed a strong absorption peak in ultraviolet region at $245 \mathrm{~nm}$ (Fig. 2). After adding of a few drops of $1 \mathrm{M} \mathrm{NaOH}$ to the solution to obtain $\mathrm{pH} 9$, the absorption peak moved to $265 \mathrm{~nm}$ and a rapid oxidation of AA started, which completed in about 15 minutes. There was no absorbancy due to the oxidation product(s) of AA (Fig. 2, curve 5).

Fig. 3. represents the absorption spectra in the near ultraviolet region of AA (curve 1), KI (curve 2) and iodine solutions (curve 3). As seen from curves 1, 2 and 3, one can expect an interferece between $\mathrm{I}, \mathrm{KI}$ and $\mathrm{AA}$ absorption spectra. To eliminate it, the iodine in $4 \%$ ethanolic solution was added to AA solution in stoichiometric amounts and a differential absorption spectrum was checked, using the expected $\mathrm{KI}$ concentration placed in the reference cell. The concentration of KI was established according to reaction: $\mathrm{I}_{2}+\mathrm{AA}=2 \mathrm{I}^{-}+2 \mathrm{H}^{+}+\mathrm{DA}$ (dehydroascorbic acid). As seen from Fig. 3, the absorption was extinguished giving almost a flat curve 4 , for DA does not show any absorption in UV region.
Fig. 2. Absorption spectra of AA solution (2.8 $\mathrm{mg} / 100 \mathrm{ml}$ of $0.05 \mathrm{M} \mathrm{HCl}$ ) - curve 1 , and after alkalization (pH about 9), checked in 2, 4.5, 9 and 15 minutes, respectively - curves $2,3,4$ and 5 .

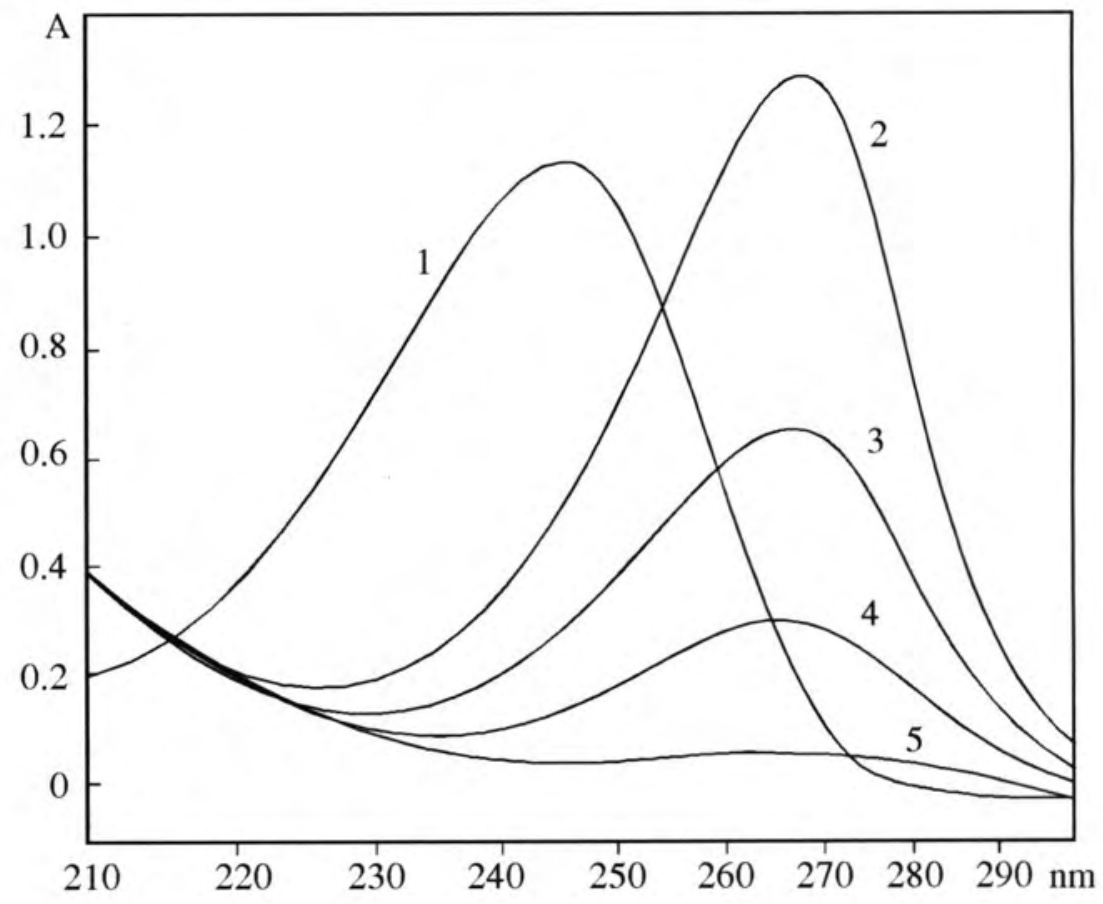




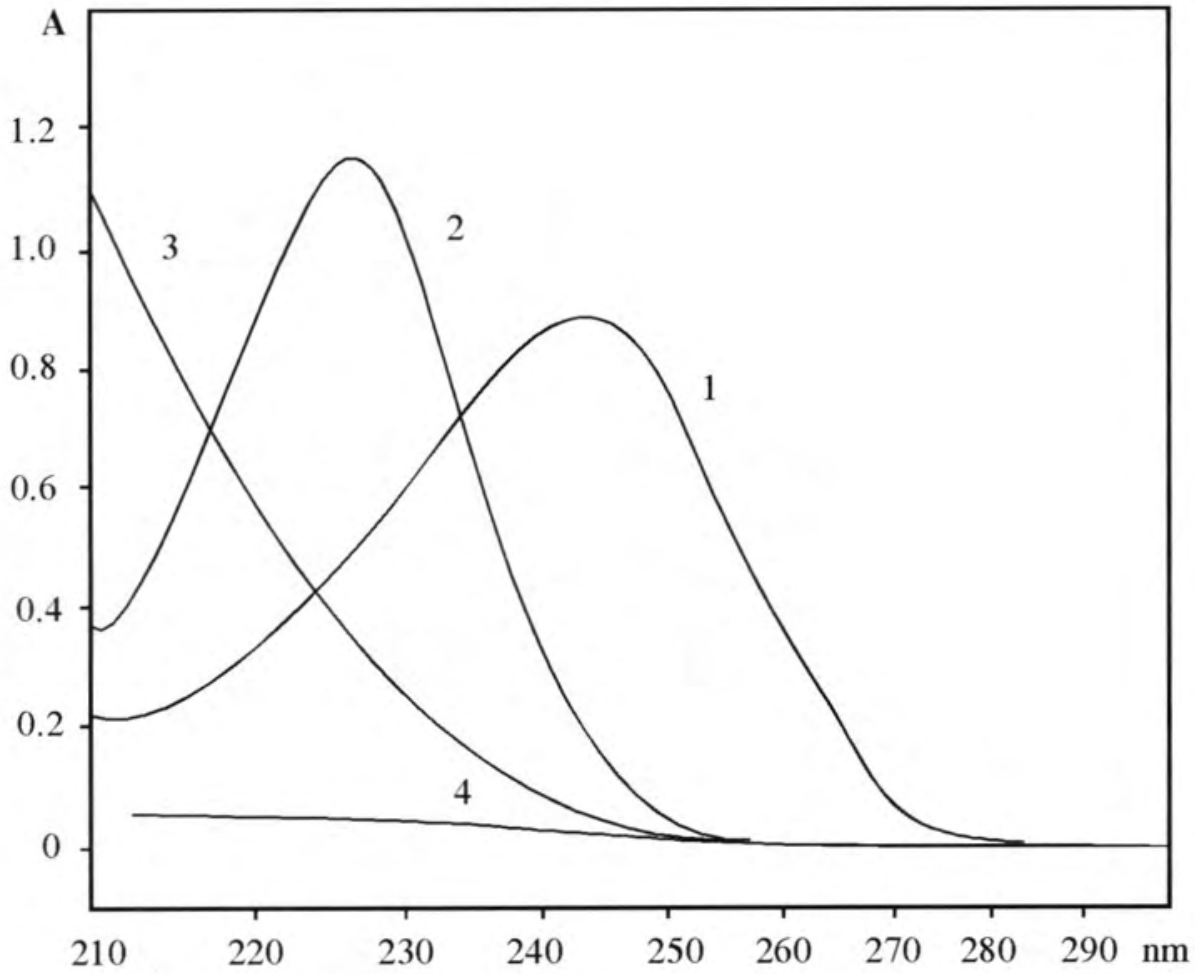

Fig. 3. Absorption spectra of: AA solution (1.90 $\mathrm{mg} / 100 \mathrm{ml}$ in $0.05 \mathrm{M} \mathrm{HCl}$ ) - curve 1 , KI solution $(1.36 \mathrm{mg} / 100 \mathrm{ml}$ of water solution) - curve 2 , and I solution $(1.36 \mathrm{mg} / 100 \mathrm{ml}$ in $4 \%$ ethanol $)$ curve 3 . Curve 4 represents differential absorption spectrum against KI solution.

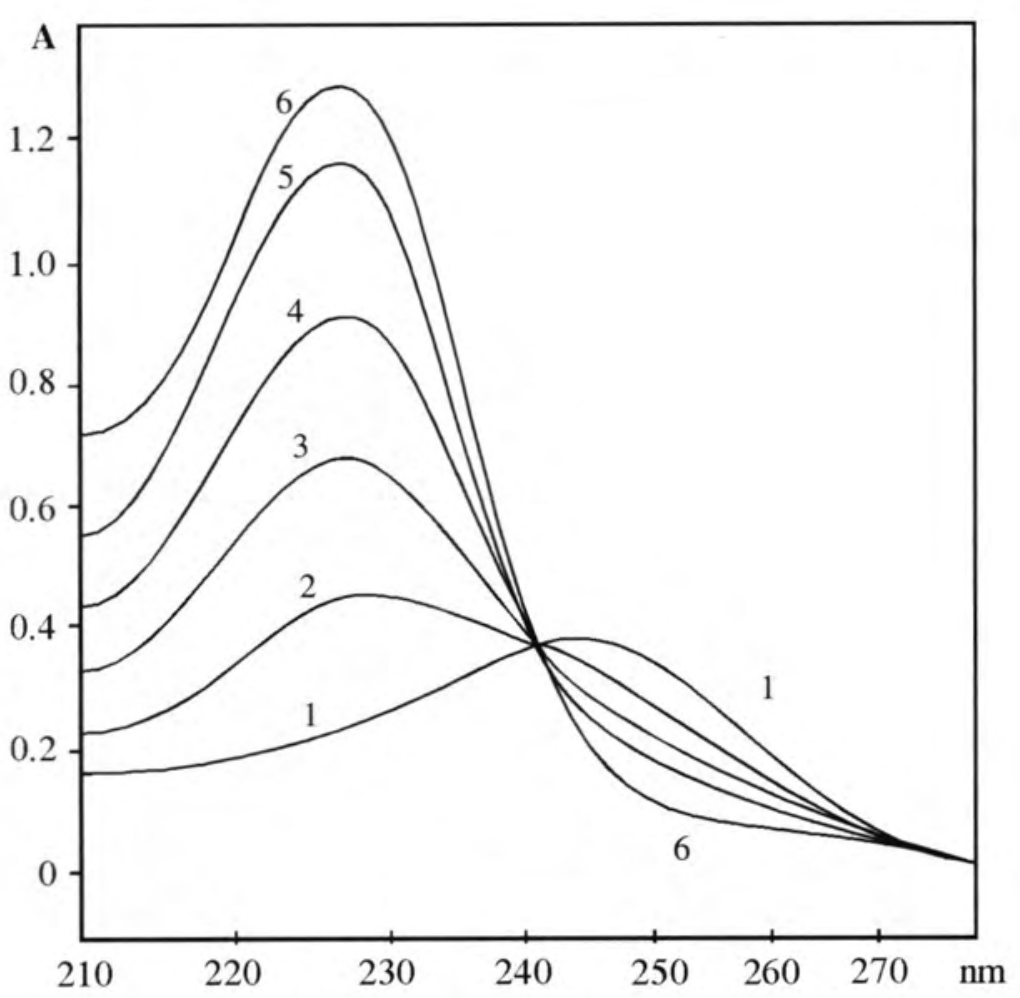

Fig. 4. Absorption spectra of the titrated AA solution: curve 1 = AA solution alone $(1.19 \mathrm{mg} / 100 \mathrm{ml}$ in $0.03 \mathrm{M} \mathrm{HCl})$, curve $2-6=18 \mathrm{mg} / 100 \mathrm{ml}$ of $\mathrm{I}$ in $2 \%$ ethanol added in 0.05 $\mathrm{ml}$ portions. The last curve 6 represents stoichiometric iodine amount added to the AA solution.
In the next experiment, the titration of AA with iodine solution in $4 \%$ ethanol was performed (Fig. 4). The reaction was followed by checking the absorption in the UV region. Curve 1 represents the absorption of AA alone. Curves 2, 3, 4, 5 and 6 were produced by succesive iodine solution adding. During AA oxidation the peak of curve 1 was shifted from $245 \mathrm{~nm}$ to the shorter region $(227 \mathrm{~nm})$ and simultaneosly was enhanced, because of KI formation. After complete AA oxidation with iodine, the produced peak corrersponded to that of KI solution (compare Fig. 3., curve 2).

\section{DISCUSSION}

A standard amount of I-KI reagent (1 ml of stock solution per $100 \mathrm{ml}$ of starch solution) protects the proportionality between starch-iodine complex and its absorbancy in the range from 1 to $7 \mathrm{ml}$ of starch added (Fig. 1). I-KI solution used in the present study in a ratio: $0.2 \mathrm{~g} \mathrm{I}$ and $2 \mathrm{~g} \mathrm{KI}$ per $100 \mathrm{ml}$ of water solution is commonly used in this kind of analysis (e. g. McCready and Hassid, 1943; Lau, 1988; Ruehl, 1989). The intensity of blue colour of the complex depends on iodide concentration (Ono et al., 1953), too. 
The present data indicate that is important to keep iodine concentration at an appropriate level. A lower iodine concentration impedes the formation of complex between spiral chains of amylose (and partly (and partly of amylopectin) with iodine, lowering the absorbancy, whereas high iodine concetration can hasten the precipitation of starch-iodine complex. We observed such a precipitation in our experiments (unpublished data).

Ascorbic acid shows the strong reducing power because of the endiol system present in the molecule. The rate of aerobic oxidation of $\mathrm{AA}$ is $\mathrm{pH}$-dependent, exibiting the maxima at $\mathrm{pH}$ 5.0 , corresponding to reaction with 1 equivalent of base, and at $\mathrm{pH} \mathrm{11.5,} \mathrm{corresponding} \mathrm{to} \mathrm{reaction} \mathrm{with} 2$ equivalents of base. The oxidation products are different. A rapid change of $\mathrm{pH}$ of the solution shifted the absorption peak of AA from 245 to $265 \mathrm{~nm}$ (Fig. 2.). According to Herbert et al. (1993), it indicates the presence of a conjugated system carrying one or more enolizable hydroksyl groups. The deterioration of endiol group is the cause of absorption peak disappearance (fig. 2.).

The disapperarance of the AA peak in ultraviolet region after iodine treatment can be explained in a similar manner. However, in this case the main structure of ascorbic acid molecule remains intact and can be regenerated from the dehydroascorbic acid by reduction with hydrogen sulfide (Hirst and Zilva, 1933). The raction of AA with iodine can be summarized:

$$
\underset{\mathrm{C}-\mathrm{OH}}{\mathrm{C}-\mathrm{OH}}+\mathrm{I}_{2}=2 \mathrm{H}^{+}+2 \mathrm{I}^{-}+\underset{\mathrm{C}=\mathrm{O}}{\mathrm{C}=\mathrm{O}}
$$

The evidence for a redox reaction between AA and I solutions is presented in Fig. 4. This reaction provides a simpler explanation for the disappearance of blue colour of starchiodine complex after addition of AA to the reaction mixture than the mechanism proposed by Sharma et al. (1990). A shift in the absorption peak to the shorter wavelengths is not necessarily a result of iodine-AA complex formation as sugested by Sharma et al. (1990). Our data indicate that the peak shift is due to the generation of iodide in the reaction between AA and I solutions.

On the basis of the present findings three measures are suggested to remove the interference of AA when starch is determined by blue iodine complex: 1) to titrate starch solution with I-KI reagent, and work out a proper amount of I-KI to develop blue colouration, 2) to remove AA from plant material either with cold water or ethanol and 3) starch solution can be treated with alkali, which destroys AA in a short time, subsequently the solution should be acidified before the complexation of starch with iodine.

\section{LITERATURE CITED}

HERBERT R. W., HIRST E. L., PERCIVAL E. G. V., REYNOLDS R. J. W., SMITH F., 1993. The composition of ascorbic acid. J. Chem. Soc. part 2, 1270-1290.

HIRST E. L., ZILVA S. S., 1933. Ascorbic acid as the antiscorbutic factor. Biochem. J. 27, 1271-1278.

LAU O. L., 1988. Harvest indices, dessert quality and storability of „Jonagold” apples in air and controlled atmosphere storage. J. Am. Soc. Hort. Sci. 113, 564-569.

McCREADY R. M., HASSID W. Z., 1943. The separation and quantitativw estimation of amylose and amylopectin in potato starch. J. Am. Chem. Soc. 65, 1154-1157.

ONO S., TSUCHIHASHI S., KUGE T., 1953. On the starch-iodine complex. J. Am. Chem. Soc. 75, 3601-3602.

RUEHL G., 1989. Rapid estimation of amylose content in peas. Landbauforsch. Volkenrode. 39, 83-86.

SAMOTUS B., TUZ J., DOERRE E., 1993. An evaluation of Blue Value in different plant materials as a tool for rapid starch determination. Acta Soc. Bot. Pol. 62, No. 3-4, 137-141.

SHARMA S. S., SHARMA S., RAI V. K., 1990. Interference of ascorbic acid with starch-iodine reaction. Ann. Botany 65, 281-283.

\section{FOTOMETRYCZNE OZNACZANIE JODO-SKROBI W MATERIAŁACH ROŚLINNYCH W OBECNOŚCI KWASU ASKORBINOWEGO. UWAGI KRYTYCZNE}

\section{STRESZCZENIE}

Analizując pracę Sharmy i in. (1990) nad negatywnym wpływem kwasu askorbinowego (AA) na reakcję jodo-skrobiową, autorzy powtórzyli tę pracę, podając poprawne wyjaśnienie wpływu AA na tę reakcję. AA utlenia odczynnik jodowo-jodkowy (I-KI) co uniemożliwia tworzenie się niebieskiego kompleksu z skrobią. Zasugerowano trzy możliwości uniknięcia zakłócenia tej reakcji przez AA: 1) można odmiareczkować roztwór za pomocą odczynnika I-KI i w ten sposób odtworzyć odpowiednią ilość I-KI celem wytworzenia niebieskiego zabarwienia, 2) można też usunąc AA (i inne substancje redukujące) z materiału roślinnego, przemywając go zimną wodą lub etanolem, 3 ) w końcu roztwór skrobiowy można potraktować ługiem przy pH ok. 9, rozkładając AA w przeciągu 15 minut. Po zakwaszeniu roztworu i dodaniu odczynnika I-KI oznacza się niebieski kompleks.

SŁOWA KLUCZOWE: kompleks jodo-skrobiowy, kwas askorbinowy. 